\begin{tabular}{|l|l|l||}
\hline \multicolumn{2}{|c|}{ PublisherInfo } \\
\hline \hline PublisherName & $:$ & BioMed Central \\
\hline \hline PublisherLocation & $:$ & London \\
\hline \hline PublisherImprintName & $:$ & BioMed Central \\
\hline \hline
\end{tabular}

\title{
Leukemia translocations
}

\begin{tabular}{|l|l|l||}
\hline \multicolumn{2}{|c|}{ ArticleInfo } \\
\hline \hline ArticleID & $:$ & 4272 \\
\hline \hline ArticleDOI & $:$ & $10.1186 /$ gb-spotlight-20011207-01 \\
\hline \hline ArticleCitationID & $:$ & spotlight-20011207-01 \\
\hline \hline ArticleSequenceNumber & $:$ & 343 \\
\hline \hline ArticleCategory & $:$ & Research news \\
\hline \hline ArticleFirstPage & $:$ & 1 \\
\hline \hline ArticleLastPage & $:$ & 2 \\
\hline \hline & & RegistrationDate : 2001-12-07 \\
ArticleHistory & $:$ & OnlineDate $\quad$ 2001-12-07 \\
\hline \hline ArticleCopyright & $:$ & BioMed Central Ltd2001 \\
\hline \hline ArticleGrants & $:$ & \\
\hline \hline ArticleContext & $:$ & 130592211 \\
\hline \hline
\end{tabular}




\section{Jonathan B Weitzman}

Email: jonathanweitzman@hotmail.com

Chromosomal translocations involving the mixed-lineage leukemia gene (MLL/ALL1) define a subset of human acute leukemias with poor prognosis. In the Advanced Online Publication of Nature Genetics, Armstrong et al. describe a gene-expression profile analysis of leukemic cells with $M L L$ translocations (DOI:10.1038/ng765). They compared the expression profiles of over 12,000 genes in B-precursor acute lymphoblastic leukemia (ALL) cells from patients with or without a rearranged $M L L$ gene. The MLL samples had a distinct profile, with about 1,000 genes underexpressed and 200 highly expressed. The gene expression pattern was characteristic of maturational arrest at an early lymphoid progenitor stage; several HOX genes were highly expressed in MLL compared to other ALL samples. Armstrong et al. used principal component analysis (PCA) to cluster the MLL, ALL (acute lymphoblastic leukemia) and AML (acute myelogenous leukemia) expression profiles. They found that MLL profiles were distinct from ALL and AML samples, and defined a set of 100 genes that could distinguish MLL from the other leukemic classes. Such studies may lead to the development of translocation-specific therapies for MLL patients.

\section{References}

1. The critical role of chromosome translocations in human leukemias.

2. Nature Genetics, [http://genetics.nature.com]

3. $M L L$ translocations specify a distinct gene expression profile that distinguishes a unique leukemia supplemental data, [http://research.dfci.harvard.edu/korsmeyer/MLL.htm] 